\title{
THE USE OF CRM INSTRUMENTS IN AGRITOURISM - ON THE EXAMPLE OF AGRITOURISM FARMS IN THE OPOLE PROVINCE
}

\author{
AGNIESZKA GAWLIK, ${ }^{1}$ BARBARA WOS ${ }^{2}$
}

RECEIVED

ACCEPTED

JEL

CLASSIFICATION

KEYWORDS

ABSTRACT

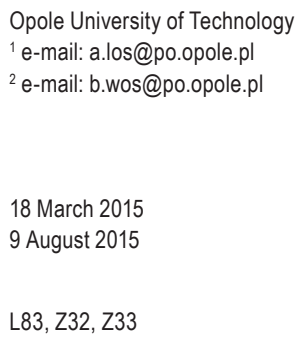

$\mathrm{L} 83, \mathrm{Z32}, \mathrm{Z33}$

agritourism farms, Opole Province, relationship management, CRM instruments

The aim of this paper is to identify key CRM instruments used by agritourism farms located in the Opole Province. In this paper documentary method and diagnostic survey method were used. In the first phase of the research, within documentary methods, an analysis of statistical material from secondary sources was conducted in order to make an inventory of agritourism farms located in the Opole Province. In this paper diagnostic survey method (CAWI) was used. Empirical study was conducted from March 2014 to April 2014 among owners of 35 agritourism farms from the Opole Province associated in Agricultural Advisory Center (AAC). The results of the study indicate which CRM instruments are the most popular in the surveyed agritourism farms in shaping relationships with customers to encourage their loyalty.

\section{Introduction}

Agritourism in Poland is a dynamically developing branch of tourism. The Opole Province is a perfect example of the region which is developing very successfully. Initially, the main task of Polish agritourism was to serve inexpensive holidays in rural areas and provide an additional source of income for the local population (Woś, Gawlik, 2015: 80-89). Nowadays, we can observe increasing standard and variety of services offered in 
agritourism farms (Puciato, 2009: 200-207; Woś, Puciato, 2011: 139-148). Agritourism farms change into small family tourist companies. Present agricultural tourism in the Opole Province is characterized by an extensive range of recreational offer as well as tourism product tailored to customer's needs (Sikora, 2002: 71-80; Graja et al., 2008: 279-287; Tew, Barbieri, 2012; Chooa, Petrick, 2014.). It seems to be extremely important in turbulent environment and growing consumer requirements that make relational marketing one of the most important ways to compete in today's touristic market (Koc, 2008: 1085-1086; Wilk, Keck-Wilk, 2013: 243-250; Flanigan et al., 2014: 394-405).

Customer relationship management (CRM) developed as a result of market changes associated mainly with a new perception of customers and their needs (Heskett et al., 1990; Zeithaml et al., 1990). This concept helps companies to understand customer needs, manage these relationships more intelligently and predict the future. CRM can be defined as an organization's attempt to build a long-term, mutually beneficial cost-effective link with a customer. It involves the strategic and tactical management to achieve positive communications and long term customer relationships.

The successful implementation of CRM requires the use of appropriate instruments for better market research, customizing products and services, obtaining higher quality products, gaining access to information and employee satisfaction, and above all, ensuring long lasting customer-retention and loyalty (Ozgener, Iraz, 2006: 1356-1363; Stockdale 2007: 205-219; Verma, Chandhuri, 2009: 55-69).

The aim of the paper is to identify the use of CRM in agritourism farms located in the Opole Province in Poland.

\section{Materials and methods}

In this paper diagnostic survey method (CAWI) was used. Empirical study was conducted as a part of multi-stage research from March 2014 to April 2014 with standardized questionnaire consisting of 25 questions among owners of 35 agritourism farms from the Opole Province associated in Agricultural Advisory Center (AAC). The cooperation with AAC enabled the authors of the paper to receive high reliability data.

\section{The resullts of the sulpvey}

Table 1 presents characteristics of surveyed entities. In most of the questions of the questionnaire survey, respondents could choose more than one answer, therefore the sum of the indications is often greater than $100 \%$.

Table 1. Characteristics of the analyzed agritourism farms

\begin{tabular}{lrr}
\hline \multicolumn{1}{c}{$\begin{array}{c}\text { Specification } \\
\text { 1 }\end{array}$} & Number & Percentage \\
\hline \multicolumn{1}{c}{ Type of offer } & 2 & 3 \\
\hline All year round & 30 & 86 \\
Seasonal & Accommodation base & 14 \\
\hline & 5 & 17 \\
\hline Guest rooms in apartment building & 22 & 63 \\
Guest rooms in a separate part of the building inhabited by the owner's family & 8 & 23 \\
Guest rooms on the same floor with the family of the owner & 1 & 3 \\
Bungalows & & \\
\hline
\end{tabular}




\begin{tabular}{|c|c|c|}
\hline & 2 & 3 \\
\hline \multicolumn{3}{|c|}{ Dining } \\
\hline OV (none) & 8 & 23 \\
\hline BB & 1 & 3 \\
\hline HB & 7 & 20 \\
\hline FB & 10 & 29 \\
\hline Local food products tasting only & 9 & 26 \\
\hline \multicolumn{3}{|c|}{ Number of Employees (including family members) } \\
\hline 1 & 3 & 9 \\
\hline 2 & 18 & 51 \\
\hline 3 & 10 & 29 \\
\hline 4 and more & 4 & 11 \\
\hline \multicolumn{3}{|c|}{ Number of beds } \\
\hline Up to 10 & 21 & 60 \\
\hline Up to 20 & 13 & 37 \\
\hline Up to 30 & 1 & 3 \\
\hline Over 30 & 0 & 0 \\
\hline \multicolumn{3}{|c|}{ Operating period (in years) } \\
\hline $1-5$ & 5 & 14 \\
\hline $6-10$ & 13 & 37 \\
\hline $11-15$ & 5 & 14 \\
\hline $16-20$ & 9 & 26 \\
\hline Up to 20 & 3 & 9 \\
\hline Total: & 35 & 100 \\
\hline
\end{tabular}

Source: authors' own studies.

In the survey the owners of agritourism farms were asked to indicate whether they undertake any actions in order to build long-term relationships with customers (Figure 1). The majority of the respondents (total $83 \%$ ) admitted that they do. Although none of the respondents denied taking such actions, the fact that $17 \%$ of the respondents stated that he/she was not sure, still indicates the lack of knowledge of the concept of the relational marketing, and points out the need to take actions to popularize it among owners of agritourism farms.

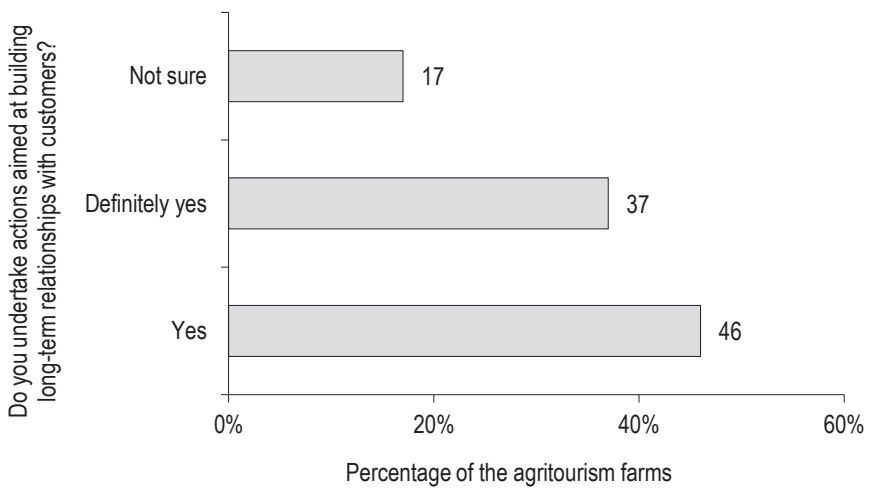

Figule 1. The use of relationship marketing in the analyzed agritourism farms 
Most of the respondents (80\%) admitted that they collect data about customers (Figure 2). Only one in five respondents admitted that such data are not collected. According to the respondents agritourism farms gather information about: history of sales (77.0\%), analysis of sales (14\%) and customer profiles (6\%) (Figure 3). These results suggest that agritourism farms collect information about customers to a limited extent and concentrate on historical records of purchase transactions.

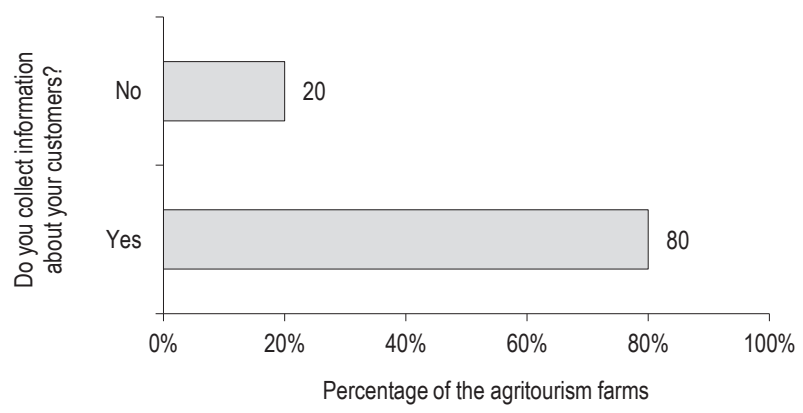

Figure 2. Collecting information about customers in the analyzed agritourism farms

Source: authors' own studies.

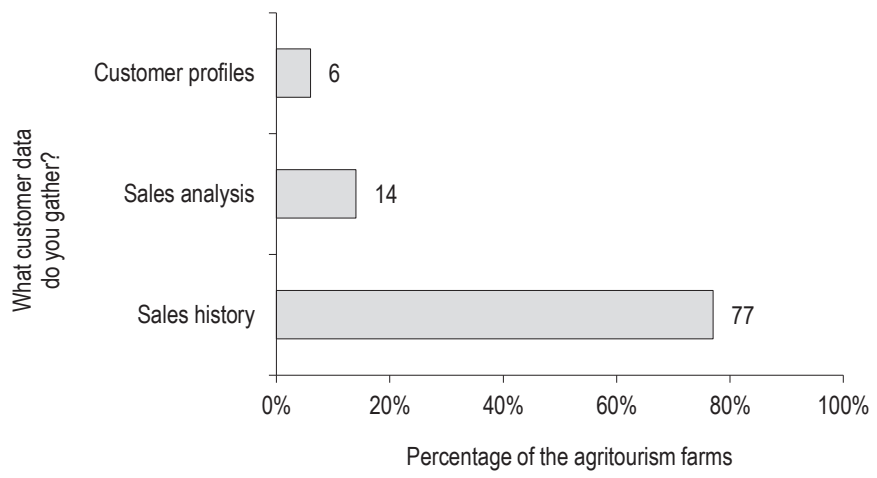

Figure 3. Customer data collected in the analyzed agritourism farms

Source: authors' own studies.

Regarding the channels of communication with customers used by agritourism farms, they are dominated by telephone calls (91\%). In second place there is an e-mail (80\%) which displaced letters sent by regular mail long ago. The growing importance of the use of information technology in communication with customers can also be seen through the emergence of new communication channels such as agrofarms' websites (37\%) or use of social networking $(6 \%)$. It should be noted that agritourism farms still rely on personal contact $(20 \%)$. It is not surprising, aslong as in agritourism particularly important role is played by a personnel providing direct services to clients. This 
is significant because agritourism farms in addition to the provision of tourist and recreational services promote local products and provide educational and informational services.

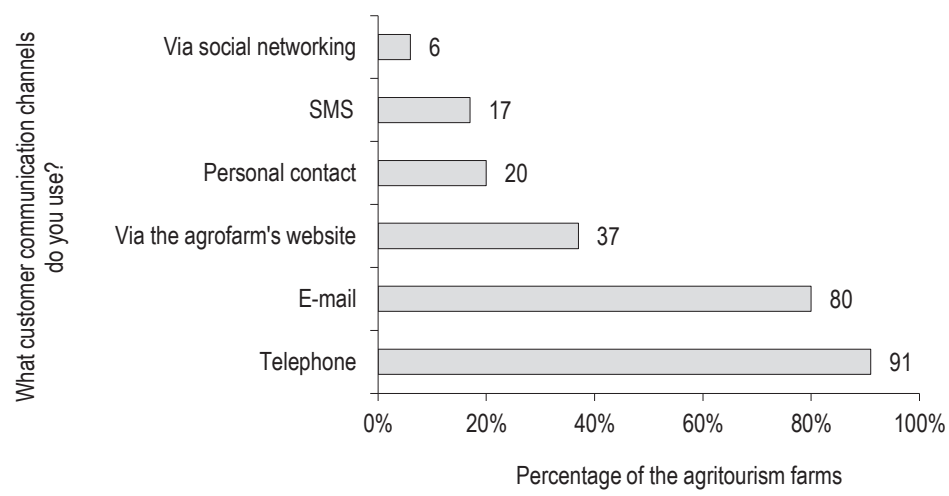

Figune 4. Customer communication channels used in the in the analyzed agritourism farms Source: authors' own studies.

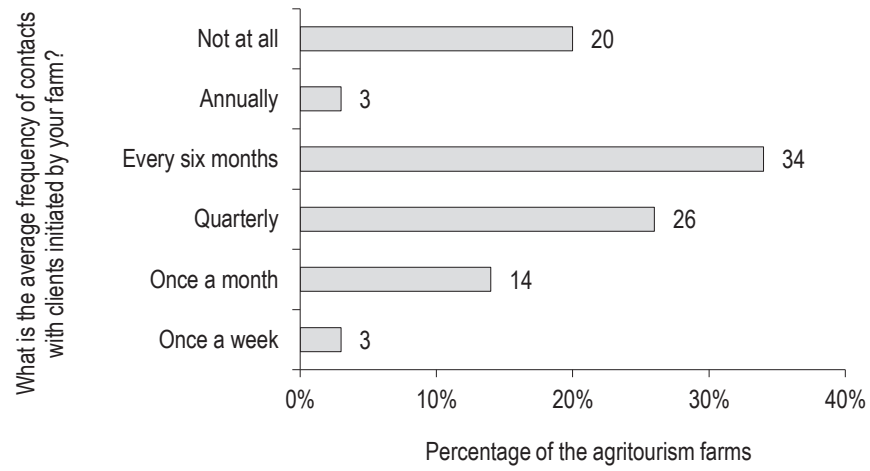

Figulp 5 . The average frequency of contacts with client initiated by the analyzed agritourism farms Source: authors' own studies.

The owners of the agritourism farms were asked about the average frequency of contacts with clients initiated by them. The highest percentage of responses fell on "every six month" answer - 34\%. Answer "once a quarter" was indicated by $26 \%$ of the respondents. One in five respondents admitted not contacting with customers at all. This is surprising since it is difficult to build long-term relationships without personalized communication that customers expect today. On the other hand, the frequency of contacts should be controlled, because information overload is negatively perceived by clients. It is particularly important to control the amount of information provided to a customer in a single communication channel. 


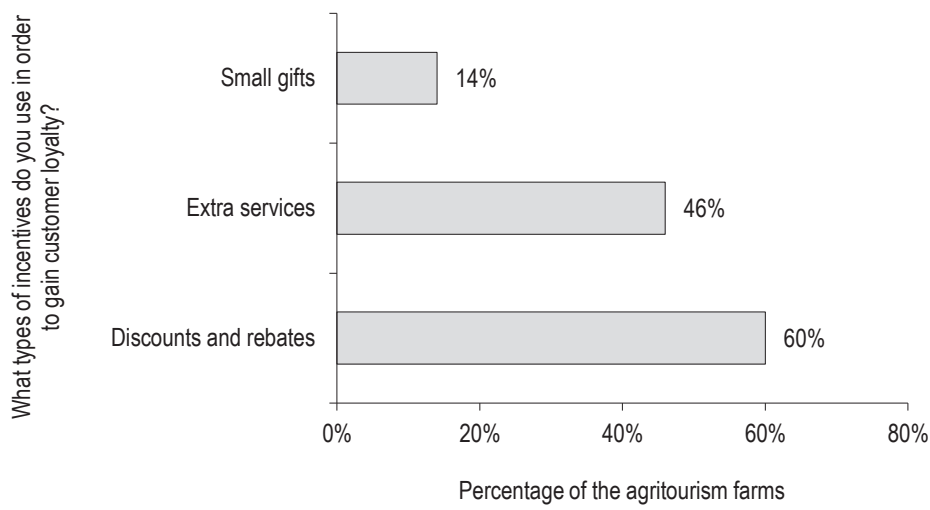

Figure $\mathfrak{b}$. The incentives used to gain customer loyalty in the analyzed agritourism farms

Source: authors' own studies.

According to the respondents, the most frequently used incentives to gain customer loyalty are discounts and rebates $(60 \%)$ which result in customer loyalty and provide an incentive to make the re-purchase. Nearly half of the respondents (46\%) declared the use of extra services. Only $14 \%$ of the agritourism farms provide their customers with small gifts $(14 \%)$.
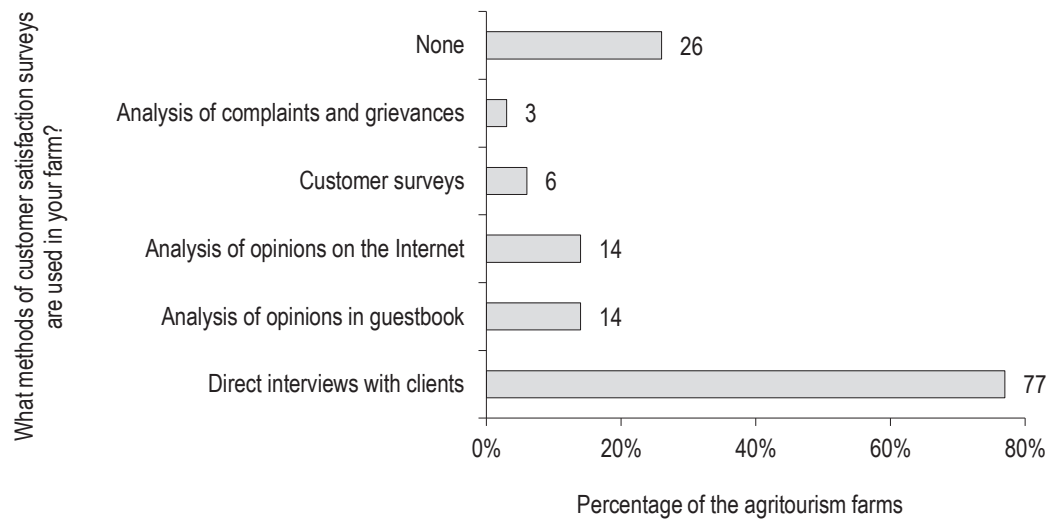

Figulp 7. Components of customer databases in the agritourism farms which collect data about their customers in databases Source: authors' own studies.

Most of the surveyed agritourism farms examine customers satisfaction (total $74 \%$ ). Due to the specificity of agritourism the most frequently methods used are direct interviews with clients (77\%). Only $14 \%$ of the agritourism farms make analysis of opinions on the Internet and analysis of opinions in guestbook. It is not surprising, as long as it can provide information about existing problems in satisfying the needs of customers and help to tailor services to customer's needs. Naturally, the role of web sources is increasing, as they provide information for clients seeking 
and comparing offers. Social networking sites allow customers to ask questions and get information about products, services and give the opportunity to express opinions.

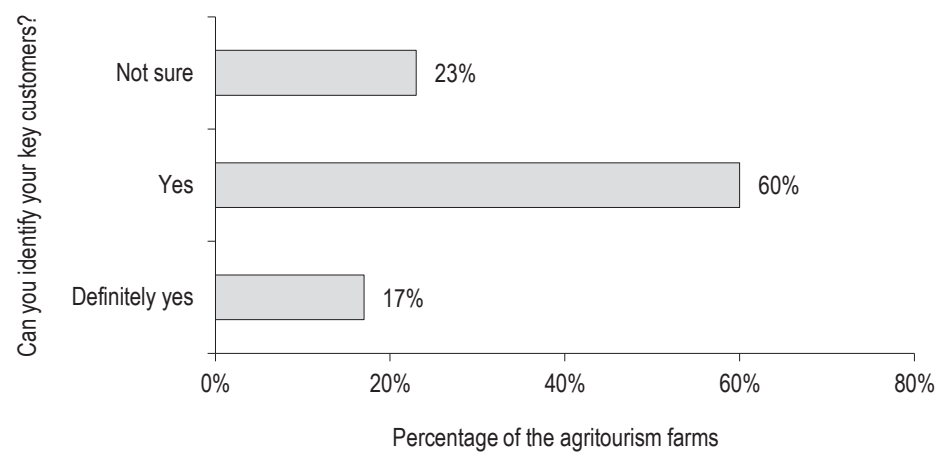

Figure 8. Special treatment of key customers in the analyzed agritourism farms

Source: authors' own studies.

In the analyzed group $77 \%$ of the respondents admitted that they can point out their key customers. Distinguishing these customers is a sign of awareness that this group generates substantial profits for the agritourism farms, and their maintenance is easier than getting new ones. Surprisingly only 1 of 3 agritourism farms admits that it treats extra selected clients.

\section{Conclusions and implications}

The agritourism farms in the Opole Province recognize the need to build long-term relationships with customers. Nearly in every fifth agritourism farm the respondents were not sure if they build long-term relationships with customers - it is necessary to continue to promote the importance of the concept of relationship marketing and its advantages among owners of agritourism farms.

In the analyzed group gathering information about customers is often exclusively limited to the analysis of historical transactions - it is necessary to extend the use of information collected e.g. for creating customers' profiles and finally for creating suitable offers.

Despite the dominant role of a phone as a channel of communication with the customer, an increasing use of modern communication channels such as social networking, e-mail or agritourism farms websites can be seen. The most frequently used incentives to gain customer loyalty are discounts and rebates. Direct interviews are very popular instrument of obtaining information about satisfaction of customers - it is necessary to promote this useful tool of continuous improvement as an instrument for building long-term relationships. A dialogue should displace one-sided messages.

The studies showed that surveyed agritourism farms strongly rely on personal contact. This draws attention to the variety of educational activities as a form of agriculture-based recreation. Local authorithies should consider the use of this channel to coordinate and develop the tourist information network in the region. 
Although most of the agritourism farms can identify key customers, only 1 of 3 entities treats these customers in a unique way - it is necessary to promote the use of key customers management among owners of the agritourism farms in the Opole Province.

These studies should be extended to other types of tourism enterprises, including business hotels, restaurants, and entities associated with tourist information and should take into account a larger number of companies located throughout the country.

\section{References}

Chooa, H. \& Petrick, J.F. (2014). Social interactions and intentions to revisit for agritourism service encounters. Tourism Management, 40: $372-381$.

Flanigan, S., Blackstock, K. \& Hunter, C. (2014). Agritourism from the perspective of providers and visitors: a typology-based study. Tourism Management, 40: 394-405.

Graja, S., Karczewska, M., Sikora, J., Jęczmyk, A., Spychała, A. (2008). Agroturystyka jako forma przedsiębiorczości na wsi. In: Gospodarka turystyczna w XXI wieku: problemy i perspektywy w skali regionalnej i lokalnej. Ed. S. Bosiacki. Poznań: Monografie AWF, 386: 279-287.

Heskett, J.L. Sasser, W.E. \& Hart, C.W.L. (1990). Breakthrough Service. New York: The Free Press.

Koc, E. (2008). The New Agritourism: Hosting Community \& Tourists on Your Farm. Annals of Tourism Research, 35 (4): 1085-1086.

Ozgener, S. \& Iraz, R. (2006). Customer relationship management in small - medium enterprises: The case of Turkish tourism industry. Tourism Management, 27 (6): 1356-1363.

Puciato, D., Winiarz, M. \& Woś, B. (2010). Rola gospodarstw agroturystycznych w realizacji koncepcji turystyki zrównoważonej w gminie Głuchołazy. Studia i Prace Uniwersytetu Adama Mickiewicza w Poznaniu - Seria Turystyka i Rekreacja, 6: 61-68.

Puciato, D. (2009). Turystyka jako szansa zrównoważonego rozwoju obszarów wiejskich. In: Społeczno-gospodarcze aspekty turystyki regionów przygranicznych. Ed. J. Rut, A. Nizioł. Rzeszów: Uniwersytet Rzeszowski (pp. 200-207).

Sikora, J. (2002). Agroturystyka przykładem przedsiębiorczości na wsi. In: Gospodarka turystyczna w XXI wieku - stan obecny i perspektywy rozwoju. Ed. S. Bosiacki. Poznań: AWF (pp. 71-80).

Stockdale, R. (2007). Managing customer relationships in the self-service environment of e-tourism. Journal of Vacation Marketing, 13 (3): 205-219.

Tew, C. \& Barbieri, C. (2012). The perceived benefits of agritourism: the provider's perspective. Tourism Management, 33 (1): 215-224.

Wilk, I. \& Keck-Wilk, M. (2013) Oczekiwania turystów dotyczące oferty gospodarstw agroturystycznych, Journal of Agribusiness and Rural Development, 2 (28): 243-250.

Woś, B. \& Gawlik, A. (2015). The development of Agri-tourism in Opole Province, Poland. From Inexpensive Holidays in the Countryside to Experiential Marketing. Journal of Environmental and Tourism Analyses, 3 (1): 80-89.

Woś, B. \& Puciato, D. (2011). Wybrane elementy oferty turystycznej gospodarstw agroturystycznych z Wysowej. Infrastruktura i Ekologia Terenów Wiejskich, 2: 139-148.

Verma, S. \& Chaundhuri, R. (2009). Effect of CRM on Customer Satisfaction in Service Sector in India. Journal of Marketing and Communication, 5 (2): 55-69.

Zeithaml, V., Parasuraman, A. \& Berry, L.L. (1990). Delivering Quality Service. New York: The Free Press.

Cite this article aS: Gawlik, A., Woś, B. (2015). The use of CRM instruments in agritourism - on the example of agritourism farms in the Opole Province. Szczecin University Scientific Journal, No. 883. Service Management, 16 (2): 49-56. 